\title{
Pengembangan Buku Ajar Matematika Terintegrasi Nilai-Nilai Keislaman Dalam Penanaman Karakter Siswa Madrasah Ibtidaiyah
}

\author{
Mohammad Kholi1 ${ }^{1}$, Lailatul Usriyah ${ }^{2}$ \\ 1,2Institut Agama Islam Negeri (IAIN) Jember \\ 1 mkholi1@iain-jember.ac.id, 2lailatulusriyah78@gmail.com
}

DOI: $10.18860 /$ mad.v12i1.7442

Abstract. Teaching materials is one important component in learning. Teaching material is packaged in an interesting learning resource so that it can help cultivation of character in student, especially elementary school students. At this age is the right time to instill the concept in children, especially concepts related to character. This is a challenge for teachers to be able to integrate concepts in subject matter with Islamic values that can help grow student character. Therefore, in this study the development of mathematics textbooks that integrated Islamic values in the character planting of Madrasah Ibtidaiyah Zainul Hasan Balung students was carried out. The purpose of this study is 1) to explain the process of compiling mathematics textbook that integrated Islamic values for the cultivation of characters in students of Madrasah Ibtidaiyah Zainul Hasan Balung; and 2) Knowing the feasibility of mathematics textbooks that integrated Islamic values for the cultivation of character in students of Madrasah Ibtidaiyah Zainul Hasan Balung. The approach and type of research used in this study is Research and Development (R\&D). Research and development are a research method used to produce certain products and test the effectiveness of these products. This research was designed using the Borg W.R. and Gall M.D. textbook development model. The development of this teaching material produces mathematics textbooks integrated Islamic values as a teacher and student companion book in learning mathematics. The resulting textbooks were tested on third grade student's "A" of MI Zainul Hasan Balung. Trial of mathematics textbook products that integrated Islamic values to find out the attractiveness or feasibility of textbooks. From the calculations using formulas, the percentage of feasibility or attractiveness of the use of mathematics textbooks that integrated Islamic values is $84.30 \%$. In accordance with the table of eligibility or validity shows that the results of the validation or the feasibility of developing a mathematic textbook that integrated Islamic values included in the category is very interesting.

Keywords. Textbooks; Islamic Values; Character

Abstrak. Materi ajar merupakan salah satu komponen penting dalam pembelajaran.
Materi ajar dikemas dalam suatu sumber belajar yang menarik sehingga bisa membantu
penanaman karakter pada siswa, khusunya siswa sekolah dasar. Pada usia ini
merupakan waktu yang tepat untuk menanamkan konsep terhadap anak khususnya
konsep yang berhubungan dengan pembentukan karakter. Hal ini menjadi tantangan
bagi guru untuk dapat mengintegrasikan antara konsep-konsep dalam materi pelajaran
dengan nilai-nilai keislaman yang dapat membantu menumbuhkan karakter pada siswa.
Oleh karena itu, pada penelitian ini dilakukan pengembangan buku ajar matematika
yang terintegrasi nilai-nilai keislaman dalam penanaman karakter pada siswa Madrasah
Ibtidaiyah Zainul Hasan Balung. Tujuan dilakukannya pengembangan buku ajar
matematika ini adalah untuk 1) menjelaskan proses penyusunan buku ajar matematika
yang terintegrasi nilai-nilai keislaman untuk penanaman karakter pada siswa Madrasah 


\section{MADRASAH}

Jurnal Pendidikan dan Pembelajaran Dasar

p ISSN: 1979-5599 | e ISSN: 2502-194X

Pag e | 53

Ibtidaiyah Zainul Hasan Balung; dan 2) Mengetahui kelayakan buku ajar matematika yang terintegrasi nilai-nilai keislaman untuk penanaman karakter pada siswa Madrasah Ibtidaiyah Zainul Hasan Balung. Pendekatan dan jenis penelitian yang digunakan dalam penelitian ini adalah Research and Development (R\&D). Penelitian dan pengembangan adalah metode penelitian yang digunakan untuk menghasilkan produk tertentu dan menguji keefektifan produk tersebut. Penelitian ini dirancang dengan menggunakan model pengembangan bahan ajar Borg, W.R dan Gall M.D. Pengembangan bahan ajar ini menghasilkan buku ajar matematika yang terintegrasi nilai-nilai keislaman sebagai buku pendamping guru dan siswa dalam pembelajaran matematika. Buku ajar yang dihasilkan diuji cobakan kepada siswa kelas IIIA MI Zainul Hasan Balung. Uji coba produk buku ajar matematika yang terintegrasi nilai-nilai keislaman untuk mengetahui kemenarikan atau kelayakan buku ajar. Dari perhitungan yang diperoleh dengan menggunakan rumus persentase kelayakan atau kemenarikan penggunaan buku ajar matematika terintegrasi nilai-nilai keislaman sebesar $84,30 \%$. Sesuai dengan tabel kelayakan atau kevalidan menunjukkan bahwa hasil validasi atau kelayakan pengembangan produk buku ajar matematika terintegrasi nilai-nilai keislaman termasuk dalam kategori sangat menarik.

Kata kunci. Buku Ajar; Nilai-nilai Keislaman; Karakter.

Received : 24-07-2019

Approved : 31-12-2019

Revised : 30-12-2019

Published : 31-12-2019

Copyright (C Madrasah Jurnal Pendidikan dan Pembelajaran Dasar. All Right Reserved.

This is an open access article under the CC BY-NC-ND license

(http:// creativecommons.org/licenses/by-nc-nd/4.0/).

Correspondence Address: mkholil@iain-jember.ac.id

\section{A. PENDAHULUAN}

Salah satu ilmu pengetahuan yang dapat diterapkan dalam kehidupan sehari-hari adalah matematika. Matematika sebagai ilmu dasar yang tidak dapat terpisahkan dengan problematika kehidupan dan dibutuhkan oleh manusia dalam menyelesaikan permasalahan sosial, ekonomi, dan alam (Fathani, 2012). Matematika merupakan suatu cara berpikir, cara menyusun kerangka dasar pembuktian logis serta perbendaharaan ide-ide dan pola-pola yang kreatif, sehingga para ahli mengatakan bahwa matematika merupakan seni berpikir yang kreatif (Fathani, 2012). Oleh karena itu, dengan mempelajari matematika diharapkan bahwa siswa dapat berpikir logis dan kreatif sehingga terbentuklah karakter pribadi siswa yang kreatif, imajinatif, berpikir logis dan sistematis.

Hal tersebut senada dengan tujuan pendidikan nasional yang termaktub dalam undang-undang Nomor 20 Tahun 2003 pasal 3 tentang pendidikan nasional bahwa "pendidikan nasional berfungsi mengembangkan kemampuan dan membentuk watak serta peradaban bangsa yang bermartabat dalam rangka mencerdaskan kehidupan bangsa, bertujuan untuk berkembangnya potensi peserta didik agar menjadi manusia yang beriman dan bertakwa kepada Tuhan Yang Maha Esa, berakhlak mulia, berilmu, 
cakap, kreatif, mandiri, dan menjadi warga negara yang demokratis serta bertanggung jawab (Fokusmedia, 2015)."

Untuk mewujudkan tujuan pendidikan nasional, yaitu terbentuknya karakter siswa perlu adanya perbaikan-perbaikan dan inovasi baru dalam sebuah pembelajaran baik dari segi penggunaan strategi pembelajarannya sampai dengan penggunaan buku dan bahan ajar dalam pembelajaran. Yang berperan penting dalam terwujudnya tujuan pendidikan nasional ini adalah guru. Seorang guru harus kreatif dan inovatif dalam merancang dan mendesain pembelajaran yang akan dilaksanakannya di kelas. Materi ajar merupakan salah satu komponen penting dalam pembelajaran. materi ajar dapat diwujudkan dalam bentuk bahan ajar. Hal ini sesuai dengan pendapat (Anggela, Masril, \& Darvina, 2013) yang menyatakan bahwa penggunaan bahan ajar dalam hal ini buku ajar yang menarik dalam pembelajaran dapat memudahkan guru menyampaikan materi sehingga siswa dapat mencapai ketuntasan dalam belajar. Oleh karena itulah, Guru harus mampu mendesain pembelajaran yang terencana dengan baik sehingga pembelajaran dapat berjalan dengan lancar dan terpusat pada siswa.

Disamping materi ajar, sumber belajar juga menjadi batu sandungan bagi guru dalam melaksanakan proses belajar. Hal ini terjadi karena beragamnya kondisi psikologis dan kemampuan siswa dalam memahami materi yang dipelajari di kelas. Anak usia sekolah dasar antara umur 7 sampai 12 tahun memiliki tahapan berpikir operasional konkrit dimana seorang anak hanya dapat menyelesaikan masalah apabila dihubungkan dengan kondisi riil (Baharuddin, 2014). Pada tahapan ini, keterlibatan mereka secara langsung dalam pembelajaran melalui benda-benda konkrit akan sangat membantu dalam mengerti dan menguasa materi. Oleh karena itu, Usia ini merupakan waktu yang tepat untuk penanaman konsep terhadap anak khususnya konsep yang berhubungan dengan pembentukan karakter. Sehingga pada tahapan belajar usia sekolah dasar inilah perlu disajikan materi ajar matematika yang dapat dipahami oleh anak khususnya materi matematika yang terintegrasi dengan nilai-nilai keislaman sehingga karakter anak dapat terbentuk melalui belajar matematika.

Langkah ini masih jarang dilakukan oleh guru sekolah dasar. Mereka masih banyak menggunakan buku-buku teks yang ada tanpa mengembangkannya menjadi buku ajar yang terintegrasi nilai-nilai keislaman yang dapat membantu terbentuknya karakter bagi anak. Hal ini juga terjadi pada lingkungan Madrasah Ibtidaiyah (MI) Zainul Hasan Balung. Berdasarkan hasil observasi awal peneliti di MI Zainul Hasan Balung, terdapat kelas reguler dan kelas full day. Pelaksanaan waktu kegiatan belajar di kelas reguler seperti halnya disekolah lainnya. Untuk waktu kegiatan belajar di kelas full day sampai dengan sore hari yang didalamnya terdapat kegiatan ekstra keagamaan.

Berdasarkan hasil wawancara dengan guru MI Zainul Hasan Balung, diperoleh fakta bahwa kelas full day ini diadakan guna untuk memberikan waktu tambahan belajar baik pelajaran sekolah dan pelajaran keagamaan. Berbeda dengan kelas full day, jam belajar kelas reguler terbatas pada jam pelajaran sekolah dasar pada umumnya. Berdasarkan Hasil wawancara dengan siswa, Salah satu siswa mengatakan bahwa dia tidak siap dalam belajar matematika, dia merasa bosan dalam belajar matematika, dia mengatakan bahwa buku ajar maupun LKS kurang menarik, justru membuat dia tidak dapat memahami materi.

Selanjutnya, berdasarkan hasil observasi diperoleh informasi bahwa dalam proses belajar mengajar guru lebih banyak menggunakan buku-buku teks atau LKS yang sudah beredar tanpa ada usaha untuk mengembangkan buku-buku atau LKS tersebut. Hal ini 


\section{MADRASAH}

Jurnal Pendidikan dan Pembelajaran Dasar

p ISSN: 1979-5599 | e ISSN: 2502-194X

Page $\mid 55$

menunjukkan bahwa guru khususnya guru matematika di sekolah tersebut kurang kreatif dalam mengembangkan bahan ajar yang terintegrasi antara matematika dan nilainilai keislaman. Erat hubungannya dengan hal tersebut, untuk memaksimalkan hasil yang diperoleh maka diperlukan pembenahan dalam proses pembelajaran matematika dan sumber belajar yang menarik bagi perserta didik dengan mengintegrasikan matematika dan nilai-nilai keislaman.

Kemampuan guru dalam merancang ataupun menyusun materi atau bahan ajar menjadi salah satu hal yang sangat berperan dalam menentukan keberhasilan proses belajar dan pembelajaran. Oleh sebab itu, sebagai pemateri dalam pembelajaran guru harus memiliki kemampuan untuk mendesain pembelajaran dengan menggunakan metode atau pendekatan yang cocok dengan keadaan siswa di dalam kelas. Terlebih dalam menyiapkan dan mengembangkan materi ajar dengan cara mengintegrasikan materi matematika dan nilai-nilai keislaman untuk mendukung kegiatan pembelajaran tersebut. Eggen \& Kauchak berpendapat bahwa dalam mendesain materi ajar atau bahan ajar seorang guru harus melakukan hal-hal berikut, yaitu (1) menyajikan berbagai macam contoh dalam materi ajar; (2) memberikan perhatian lebih pada komunikasi antara siswa dalam proses pembelajaran; (3) menyajikan materi matematika yang dihubungkan dengan benda-benda konkrit yang berada di lingkungan sekitar siswa (Cai, Kaiser, Perry, \& Wong, 2009). Dari materi ajar yang telah dikembangkan tersebut selanjutnya diwujudkan ke dalam bahan ajar untuk membantu siswa supaya lebih mudah dalam mempelajarinya.

Erat hubungannya dengan hal tersebut, maka keberadaan bahan ajar sangat dibutuhkan untuk mendukung pelaksanaan pembelajaran dan meningkatkan hasil belajar matematika siswa. Selanjutnya bahan ajar tersebut digunakan dengan mengimplementasikan pembelajaran bermakna. Belajar bermakna dapat digunakan antara lain dengan menyajikan problem-problem yang dapat menghubungkan konsep dasar yang telah dimiliki siswa dengan konsep-konsep yang akan disampaikan. Akan tetapi faktanya bahwa saat ini masih minim tersedianya buku ajar matematika terintegrasi nilai-nilai keislaman yang didesain dengan proses pembelajaran bermakna dan dapat membantu tercapainya pembelajaran matematika sesuai dengan tuntutan kurikulum.

Bahan ajar yang digunakan selama ini yaitu buku-buku pelajaran yang kontainnya berupa materi-materi dan latihan-latihan soal, sehingga pembelajaran yang diterapkan bersifat teacher-centered. Akibatnya siswa kurang maksimal dalam menerima materi yang telah dipelajari, baik pengetahuan maupun ketrampilannya. Padahal telah dijelaskan dalam Permendikbud Nomor 68 Tahun 2013, bahwa pendekatan yang diterapkan untuk menjadikan siswa aktif dalam pembelajaran dengan menggunakan pendekatan saintifik. Pendekatan ini lebih mengutamakan keaktifan siswa dalam menemukan suatu konsep. Dengan demikian pembelajaran bersifat student-centered.

Guru seyogyanya dapat membuat bahan ajar matematika yang di dalamnya berisi kegiatan pembelajaran abab 21 yang lebih menekankan pada kemampuan 4C, yaitu ctitical thinking, communication, collaboration, dan creativity (Sugiyarti, Arif, \& Mursalin, 2018) serta dapat menentukan strategi dan pendekatan belajar yang sesuai dengan keadaan di sekolah tersebut dengan mengintegrasikan matematika dan nilai-nilai 
keislaman, sehingga pembelajaran menjadi lebih bermakna dan hasil belajar matematika siswa menjadi lebih baik.

Untuk menjadikan kegiatan pembelajaran lebih bermakna bagi siswa, maka desain pembelajaran yang diterapkan di dalam kelas maupun bahan ajar yang telah disiapkan hendaknya dihubungkan dengan kehidupan sehari-hari siswa. Supaya belajar bermakna dapat terjadi, konsep yang baru atau informasi-informasi baru harus dihubungkan dengan konsep-konsep yang telah ada dalam struktur kognitif siswa. struktur kognitif yang telah dimiliki siswa akan sangat menunjang berhasil atau tidaknya proses pembelajaran (Hamzah \& Muhlisrarini, 2014).

Pada kegiatan pembelajaran matematika, apabila seorang guru dapat menghubungkan materi pelajaran yang dibahas dengan keadaan siswa, baik hobi siswa, struktur kognitif, lingkungan sekitar, dan bekal yang dimiliki siswa, maka akan memilikir pengaruh positif bagi siswa yaitu pembelajaran tersebut menjadi menyenangkan (joyfull learning) (Samani, 2011). Sudah sepantasnya seorang guru untuk mendesain bahan ajar yang sesuai dengan kebutuhan siswa dan mendukung dalam pelaksanaan pembelajaran. Bukan sekedar bahan ajar yang sudah tersedia melalui percetakan-percetakan tanpa memperhatikan kebutuhan dan kondisi siswa di sekolah masing-masing. Sebagaimana yang telah diatur dalan undang-undang SISDIKNAS 11 tahun 2005, yaitu "buku pelajaran merupakan buku acuan wajib untuk digunakan di sekolah yang memuat materi pembelajaran dalam rangka peningkatan keimanan dan ketaqwaan, budi pekerti dan kepribadian, kemampuan penguasaan ilmu pengetahuan dan teknologi, kemampuan dan kepekaan estetis, potensi fisik dan kesehatan yang disusun berdasarkan standar nasional pendidikan" (Fokusmedia, 2015).

Salah satu bentuk dari bahan ajar adalah buku siswa. Dalam hal ini (Trianto, 2013) berpendapat bahwa buku siswa adalah buku pedoman siswa dalam proses pembelajaran yang berisi tentang materi, kegiatan penyelidikan sesuai konsep, informasi-informasi, dan berbagai macam contoh penerapan matematika dalam kehidupan sehari-hari. Selain itu, buku siswa ini juga sebagai pedoman belajar baik dalam belajar mandiri maupun proses pembelajaran di kelas.

Sesuai dengan paparan di atas, dalam penelitian ini yang dimaksud dengan buku siswa adalah buku pedoman siswa yang berisi tentang problem-problem dan modelmodel penerapan matematika yang berhubungan dengan kehidupan sehari-hari dengan tujuan supaya siswa bisa memperoleh sendiri konsep-konsep yang ada dalam matematika. Misalnya menemukan konsep operasi bilangan pada pembelajaran matematika. Selain itu, buku siswa ini berisi tentang kegiatan siswa, kesimpulan dari kegiatan, dan berakhir dengan soal-soal cerita. Guru dapat menggunakan soal-soal latihan dalam buku siswa sebagai alternatif pekerjaan rumah siswa. Buku siswa yang baik adalah buku siswa yang desainnya menarik dengan gaya bahasa yang sesuai dengan kaidah bahasa indonesia dan mudah dimengerti yang dilengkapi dengan gambar serta penjelesannya.

Berdasarkan uraian tentang fakta permasalahan tersebut, maka peneliti akan melakukan penelitian pengembangan untuk menghasilkan produk berupa buku ajar matematika untuk siswa MI Zainul Hasan Balung yang mengintegrasikan matematika dan nilai-nilai Keislaman guna mengatasi permasalahan-permasalahan dalam pembelajaran matematika. Judul dalam penelitian ini yaitu “Pengembangan Buku Ajar Matematika Terintegrasi Nilai-Nilai Keislaman Dalam Penanaman Karakter Pada Siswa Madrasah Ibtidaiyah (MI) Zainul Hasan Balung" 


\section{MADRASAH}

Jurnal Pendidikan dan Pembelajaran Dasar

p ISSN: 1979-5599 | e ISSN: 2502-194X

Page $\mid 57$

Berdasarkan latar belakang yang telah dipaparkan di atas, dapat dirumuskan permasalahan sebagai berikut: 1) Bagaimana proses penyusunan buku ajar matematika terintegrasi nilai-nilai keislaman untuk penanaman karakter siswa Madrasah Ibtidaiyah (MI) Zainul Hasan Balung?; 2) Bagaimana kelayakan buku ajar matematika terintegrasi nilai-nilai keislaman untuk penanaman karakter siswa Madrasah Ibtidaiyah (MI) Zainul Hasan Balung?. Adapun tujuan penelitian ini adalah 1) Menjelaskan proses penyusunan buku ajar matematika terintegrasi nilai-nilai keislaman untuk penanaman karakter siswa Madrasah Ibtidaiyah (MI) Zainul Hasan Balung; 2) Mengetahui kelayakan buku ajar matematika terintegrasi nilai-nilai keislaman untuk penanaman karakter siswa Madrasah Ibtidaiyah (MI) Zainul Hasan Balung.

\section{B. METODE}

Pendekatan dan jenis penelitian yang digunakan dalam penelitian ini adalah penelitian dan pengembangan atau Research and Development. Research and Development adalah metode penelitian yang digunakan untuk menghasilkan produk tertentu dan menguji keefektifan produk tersebut. Menurut Borg and Gall, Research and Development merupakan metode penelitian yang digunakan untuk mengembangkan atau memvalidasi produk-produk yang digunakan dalam pendidikan dan pembelajaran (Sugiyono, 2016). Kemudian menurut (Sugiyono, 2015), Research and Development adalah metode penelitian yang digunakan untuk menghasilkan produk tertentu dan menguji keefektifan produk tersebut yang digunakan untuk mengantisipasi masalah dalam bidang pendidikan.

Subjek uji coba adalah seseorang yang terlibat langsung dalam pengujian produk buku ajar. Subjek uji coba produk pengembangan buku ajar yang terintegrasi nilai-nilai keislaman ini adalah ahli isi bidang studi matematika, ahli desain bahan ajar, sasaran user (guru dan siswa kelas IIIA MI Zainul Hasan Balung yang berjumlah 27 siswa). Penelitian ini didesain dengan mengadopsi model pengembangan bahan ajar Borg, W.R dan Gall M.D. Borg dan Gall menggunakan 10 langkah prosedural dalam pengembangan bahan ajar. Adapun langkah-langkah diadopsi peneliti dari pengembangan buku ajar dalam penelitian ini hanya menggunakan 5 langkah pengembangan, yaitu: 1) Penelitian dan pengumpulan informasi awal (Research and information collecting); 2) Perencanaan (planning); 3) Pengembangan format produk awal (Develop Preliminary form of product); 4) Revisi produk (Main Product Revision); 5) Uji coba lapangan (Main Field Testing) (Sugiyono, 2016).

\section{HASIL DAN PEMBAHASAN}

Sebelum pengembangan buku ajar matematika dilakukan, terlebih dahulu dilaksanakan analisis kurikulum dan analisis kebutuhan. Buku ajar dalam hal ini adalah buku siswa. Pada penelitian ini, buku siswa yang dikembangkan mencerminkan karakteristik belajar berbasis masalah yang diintegrasikan dengan nilai-nilai keislaman karena pada buku tersebut memuat masalah yang berkaitan dengan kehidupan seharihari siswa, aktivitas-aktivitas yang mengarahkan siswa menemukan konsep dan menerapkannya, dan soal-soal latihan sebagai latihan pemantapan siswa dalam memahami konsep-konsep yang diterima. Dengan desain buku ajar matematika terintegrasi nilai-nilai islam yang baik dan menarik, diharapkan dapat memudahkan 
siswa dalam memahami konsep matematika dan pengetahuan agama dengan mudah sehingga terbentuklah karakter yang baik dalam diri siswa. (Anggela et al., 2013) menyatakan bahwa pembalajaran akan lebih efektif dengan menggunakan buku ajar terintegrasi nilai-nilai keislaman dalam membangun nilai-nilai karakter siswa. Adapaun fase pengembangan buku ajar matematika terintegrasi nilai-nilai keislaman diuraikan sebagai berikut.

\section{Fase Proses Pengembangan Buku Ajar Matematika Terintegrasi Nilai-Nilai Keislaman}

Terdapat lima tahapan yang peneliti lakukan dalam melaksanakan proses dalam penelitian pengembangan ini, yaitu tahap pra pengembangan, tahap pengembangan, tahap validasi produk, tahap revisi produk, dan tahap uji coba produk. Pada tahapan pra pengembangan, peneliti melakukan observasi awal untuk mengamati proses kegiatan pembelajaran yang berlangsung dan mengamati karakteristik siswa pada tahapan pembelajaran tersebut. Selain itu, wawancara juga dilakukan peneliti kepada guru kelas IIIA yaitu Yunia untuk mengetahui lebih lanjut karakteristik siswa, sumber-sumber belajar yang mendukung dan hasil belajar siswa. Setelah memperoleh informasi lebih dalam dari guru mengenai kondisi siswa kelas IIIA, selanjutnya kompetensi inti dan kompetensi dasar yang akan digunakan dalam pengembangan bahan ajar ditentukan oleh peneliti.

Tahapan berikutnya adalah pengembangan format produk awal. Pada tahapan ini peneliti memulai membuat dan mengembangkan produk bahan ajar yang akan digunakan dalam penelitian. Dalam mengembangkan bahan ajar terdapat beberapa hal yang dilakukan oleh peneliti antara lain menentukan materi yang akan digunakan dalam pembelajaran, membuat dan mengembangkan produk bahan ajar matematika kelas III terintegrasi nilai-nilai keislaman. Setelah membuat buku ajar terintegrasi nilai-nilai keislman, langkah yang dilakukan selanjutnya adalah validasi kepada tim ahli yang terdiri dari ahli desain materi dan praktisi pembelajaran untuk melihat kelayakan bahan ajar sebelum menggunakannya dalam penelitian. Peneliti melakukan perbaikan apabila terdapat revisi atau masukan-masukan dari tim validator. Tahap selanjutnya adalah uji coba produk bahan ajar yang terintegrasi nilai-nilai keislaman untuk melihat kemenarikan buku ajar yang telah dikembangkan. Langkah-langkah tersebut dilaksanakan berpedoman pada tahapan pengembangan Borg dan Gall.

\section{Hasil Validasi Produk Pengembangan Buku Ajar Matematika Terintegrasi Nilai- Nilai Keislaman}

Validasi oleh tim ahli dilakukan sebanyak tiga orang ahli. Dua orang ahli materi dari unsur dosen yaitu dosen agama dan dosen pendidikan matematika serta satu orang praktisi pembelajaran (guru matematika). Data yang didapatkan berupa data kuantitatif yang diperoleh dari angket penilaian yang didesain dengan menggunakan skala likert dengan alternatif lima jawaban.

Validasi pertama dilakukan oleh ahli matematika. Validasi ahli matematika dilakukan pada tanggal 29 September 2018. Hasil produk pengembangan yang divalidasi oleh ahli matematika adalah buku ajar matematika kelas III materi operasi hitung perkalian dan pembagian yang terintegrasi nilai-nilai keislaman dengan menggunakan angket. Data kuantitatif yang diperoleh dari angket hasil penilaian produk buku ajar matematika terintegrasi nilai-nilai keislaman adalah $80 \%$. Sesuai dengan tabel kevalidan 


\section{MADRASAH}

Jurnal Pendidikan dan Pembelajaran Dasar

p ISSN: 1979-5599 | e ISSN: 2502-194X

Page $\mid 59$

atan kelayakan, maka hasil validasi ahli matematika terhadap hasil pengembangan buku ajar matematika terintegrasi nilai-nilai keislaman termasuk dalam kriteria valid dan tidak revisi. Validasi selanjutnya adalah validasi ahli agama. Validasi ahli agama juga dilakukan pada tanggal 29 September 2018. Adapun data kuantitatif yang diperoleh dari angket hasil penilaian buku ajar matematika terintegrasi nilai-nilai keislaman adalah $86 \%$. Sesuai dengan tabel kevalidan atan kelayakan, maka hasil validasi dari ahli agama terhadap produk pengembangan buku ajar matematika terintegrasi nilai-nilai keislaman termasuk dalam kriteria sangat valid dan tidak revisi. Validasi ketiga adalah validasi praktisi pembelajaran. Dalam hal ini dilakukan oleh guru matematika. Adapun data kuantitatif yang diperoleh dari angket hasil penilaian produk buku ajar matematika yang terintegrasi nilai-nilai keislaman sebesar $82 \%$. sesuai dengan tabel kevalidan atau kelayakan, maka hasil validasi dari praktisi pembelajaran terhadap produk pengembangan buku ajar matematika terintegrasi nilai-nilai keislaman termasuk dalam kriteria valid dan tidak revisi. Hasil validasi dari ketiga validator menunjukkan bahwa produk pengembangan buku ajar matematika terintegrasi nilai-nilai keislaman berada pada kategori tidak ada revisi. Ini menunjukkan bahwa produk bahan ajar berupa buku ajar yang telah dikembangkan dapat digunakan untuk uji coba dilapangan.

\section{Uji Coba Produk dan Penilaian Kemenarikan Buku Ajar Matematika Terintegrasi Nilai-Nilai Keislaman}

Setelah dinyatakan valid dan tidak ada revisi oleh validator, selanjutnya peneliti melakukan uji coba produk buku ajar matematika terintegrasi nilai-nilai keislaman kepada siswa kelas IIIA Madrasah Ibtidaiyah Zainul Hasan Balung. Uji coba dilaksanakan sesuai dengan jadwal pembelajaran di sekolah, yaitu hari kamis dan sabtu. Pelaksanaan uji coba sebanyak enam pertemuan, yaitu hari kamis pada tanggal 11 Oktober 2018, 18 Oktober 2018, dan 25 Oktober 2018 serta hari sabtu pada tanggal 13 Oktober 2018, 20 Oktober 2018, dan 27 Oktober 2018. Pada uji coba ini yang bertindak sebagai guru adalah guru matematika yang mengajar di kelas IIIA tersebut. Sedangkan yang bertindak sebagai observer pada uji coba ini adalah dua orang dosen Pendidikan Guru Madrasah Ibtidaiyah Institut Agama Islam Negeri Jember.

Setelah selesai dilaksanakan uji coba produk buku ajar terintegrasi nilai-nilai keislaman, selanjutnya peneliti menyebarkan angket penilaian kemenarikan buku ajar yang telah digunakan. Angket penilaian kemenarikan yang disebar berjumlah sepuluh item soal dengan pertanyaan-pertanyaan berikut: 1) Buku ajar matematika terintegrasi nilai-nilai keislaman memudahkan siswa dalam belajar matematika; 2) Buku ajar matematika terintegrasi nilai-nilai keislaman membantu siswa dalam menambah pengetahuan agama; 3) Penggunaan buku ajar matematika siswa dapat menambah semangat siswa dalam belajar; 4) Materi pelajaran dalam buku ajar matematika terintegrasi nilai-nilai keislaman mudah dipahami; 5) Soal-soal dalam buku ajar matematika terintegrasi nilai-nilai keislaman mudah dipahami; 6) Kata-kata dalam buku ajar matematika terintegrasi nilai-nilai keislaman sesuai dengan kemampuan siswa; 7) Penggunaan buku ajar matematika terintegrasi nilai-nilai keislaman dapat menumbuhkan semangat belajar mandiri siswa; 8) Bahasa yang digunakan dalam buku ajar matematika terintegrasi nilai-nilai keislaman mudah dipahami; 9) Jenis huruf dan ukurannya dalam buku ajar matematika terintegrasi nilai-nilai keislaman memudahkan 
siswa membaca; dan 10) Petunjuk dalam buku ajar matematika terintegrasi nilai-nilai keislaman mudah dipahami.

Angket tersebut disebarkan kepada responden yaitu siswa kelas IIIA yang berjumlah 27 siswa. Adapun data yang diperoleh dari hasil penyebaran angket tersebut adalah sebagai berikut.

Tabel C.1 Hasil penilaian angket kemenarikan

\begin{tabular}{|c|c|c|c|c|c|c|c|c|c|c|}
\hline \multirow{2}{*}{ Responden } & \multicolumn{10}{|c|}{ Item Soal } \\
\hline & 1 & 2 & 3 & 4 & 5 & 6 & 7 & 8 & 9 & 10 \\
\hline 1 & 4 & 4 & 4 & 4 & 4 & 5 & 5 & 4 & 4 & 5 \\
\hline 2 & 5 & 5 & 3 & 4 & 5 & 4 & 4 & 4 & 4 & 3 \\
\hline 3 & 3 & 4 & 4 & 5 & 4 & 4 & 4 & 4 & 4 & 4 \\
\hline 4 & 4 & 5 & 4 & 4 & 5 & 5 & 4 & 5 & 5 & 4 \\
\hline 5 & 4 & 4 & 5 & 5 & 4 & 4 & 4 & 5 & 4 & 4 \\
\hline 6 & 4 & 5 & 4 & 4 & 4 & 5 & 5 & 4 & 4 & 4 \\
\hline 7 & 4 & 4 & 4 & 4 & 4 & 4 & 4 & 5 & 4 & 4 \\
\hline 8 & 3 & 5 & 4 & 4 & 5 & 5 & 4 & 4 & 5 & 4 \\
\hline 9 & 3 & 4 & 4 & 5 & 4 & 4 & 5 & 5 & 4 & 4 \\
\hline 10 & 4 & 4 & 3 & 4 & 4 & 5 & 4 & 5 & 4 & 5 \\
\hline 11 & 4 & 4 & 4 & 4 & 5 & 5 & 5 & 4 & 4 & 4 \\
\hline 12 & 3 & 5 & 3 & 4 & 4 & 4 & 4 & 4 & 4 & 5 \\
\hline 13 & 4 & 4 & 4 & 4 & 5 & 5 & 4 & 5 & 4 & 4 \\
\hline 14 & 3 & 4 & 4 & 4 & 5 & 4 & 4 & 4 & 4 & 5 \\
\hline 15 & 4 & 4 & 4 & 4 & 4 & 5 & 4 & 5 & 4 & 4 \\
\hline 16 & 3 & 4 & 4 & 4 & 5 & 4 & 4 & 5 & 4 & 4 \\
\hline 17 & 5 & 5 & 4 & 4 & 4 & 4 & 4 & 5 & 4 & 4 \\
\hline 18 & 4 & 4 & 4 & 4 & 4 & 4 & 4 & 5 & 4 & 4 \\
\hline 19 & 3 & 4 & 4 & 5 & 5 & 4 & 4 & 4 & 4 & 5 \\
\hline 20 & 4 & 5 & 4 & 4 & 5 & 4 & 5 & 5 & 4 & 4 \\
\hline 21 & 3 & 4 & 5 & 4 & 4 & 4 & 4 & 4 & 4 & 5 \\
\hline 22 & 4 & 4 & 4 & 5 & 4 & 4 & 4 & 4 & 5 & 4 \\
\hline 23 & 4 & 4 & 4 & 4 & 4 & 4 & 5 & 5 & 4 & 5 \\
\hline 24 & 4 & 5 & 5 & 4 & 4 & 4 & 4 & 5 & 4 & 4 \\
\hline 25 & 3 & 4 & 4 & 5 & 5 & 4 & 4 & 4 & 5 & 5 \\
\hline 26 & 4 & 4 & 4 & 4 & 4 & 4 & 4 & 5 & 4 & 5 \\
\hline 27 & 4 & 4 & 4 & 4 & 4 & 4 & 5 & 4 & 4 & 4 \\
\hline Jumlah X & 101 & 116 & 108 & 114 & 118 & 116 & 115 & 122 & 112 & 116 \\
\hline Skor Maks $\left(X_{i}\right)$ & 135 & 135 & 135 & 135 & 135 & 135 & 135 & 135 & 135 & 135 \\
\hline $\mathrm{P}(\%)$ & 74,81 & 85,93 & 80,00 & 84,44 & 87,41 & 85,93 & 85,19 & 90,37 & 82,96 & 85,93 \\
\hline
\end{tabular}

Dari data pada tabel 1 di atas dapat dilihat bahwa setiap item soal yang diberikan kepada 27 responden menghasilkan kriteria kemenarikan sebagai berikut:

1. Item soal pertama diperoleh persentase sebesar $74,81 \%$ yang apabila dicocokkan dengan tabel kevalidan atau kelayakan berada pada kategori layak atau menarik. 


\section{MADRASAH}

Jurnal Pendidikan dan Pembelajaran Dasar

p ISSN: 1979-5599 | e ISSN: 2502-194X

Page | 61

2. Item soal kedua diperoleh persentase sebesar 85,93\% yang apabila dicocokkan dengan tabel kevalidan atau kelayakan berada pada kategori sangat layak atau sangat menarik.

3. Item soal ketiga diperoleh persentase sebesar $80,00 \%$ yang apabila dicocokkan dengan tabel kevalidan atau kelayakan berada pada kategori layak atau menarik.

4. Item soal keempat diperoleh persentase sebesar $84,44 \%$ yang apabila dicocokkan dengan tabel kevalidan atau kelayakan berada pada kategori sangat layak atau sangat menarik.

5. Item soal kelima diperoleh persentase sebesar $87,41 \%$ yang apabila dicocokkan dengan tabel kevalidan atau kelayakan berada pada kategori sangat layak atau sangat menarik.

6. Item soal keenam diperoleh persentase sebesar $85,93 \%$ yang apabila dicocokkan dengan tabel kevalidan atau kelayakan berada pada kategori sangat layak atau sangat menarik.

7. Item soal ketujuh diperoleh persentase sebesar $85,19 \%$ yang apabila dicocokkan dengan tabel kevalidan atau kelayakan berada pada kategori sangat layak atau sangat menarik.

8. Item soal kedelapan diperoleh persentase sebesar $90,37 \%$ yang apabila dicocokkan dengan tabel kevalidan atau kelayakan berada pada kategori sangat layak atau sangat menarik.

9. Item soal kesembilan diperoleh persentase sebesar $82,96 \%$ yang apabila dicocokkan dengan tabel kevalidan atau kelayakan berada pada kategori layak atau menarik.

10. Item soal kesepuluh diperoleh persentase sebesar $85,93 \%$ yang apabila dicocokkan dengan tabel kevalidan atau kelayakan berada pada kategori sangat layak atau sangat menarik.

Berdasarkan perolehan data di atas, dapat diperoleh informasi mengenai persentase kemenarikan buku ajar yang terintegrasi nilai-nilai keislaman dengan cara sebagai berikut.

$$
P=\frac{\sum X}{\sum X_{i}} \times 100 \%=\frac{1138}{1350} \times 100 \%=84,30 \%
$$

Dimana $\sum X$ adalah jumlah seluruh jumlah skor per item; $\sum X_{i}$ adalah jumlah skor maksimal per item. Dari perhitungan tersebut diperoleh persentase kelayakan atau kemenarikan penggunaan buku ajar matematika terintegrasi nilai-nilai keislaman sebesar 84,30\%. Sesuai dengan tabel kelayakan atau kevalidan menunjukkan bahwa hasil validasi atau kelayakan pengembangan produk buku ajar matematika terintegrasi nilainilai keislaman termasuk dalam kategori sangat menarik.

\section{KESIMPULAN}

Setelah dilakukan pengembangan dan uji coba terhadap buku ajar matematika terintegrasi nilai-nilai keislaman di kelas III A MI Zainul Hasan Balung, kesimpulan yang dapat diperoleh adalah:

1. Pengembangan bahan ajar ini menghasilkan buku ajar matematika terintegrasi nilainilai keislaman sebagai buku pendamping guru dan siswa dalam pembelajaran matematika. Pembelajaran dengan menggunakan buku ajar matematika terintegrasi 
nilai-nilai keislaman ini dapat mempermudah guru dalam mengajarkan nilai-nilai agama kepada siswa dalam pembelajaran matematika di kelas III MI Zainul Hasan Balung.

2. Uji coba produk buku ajar matematika terintegrasi nilai-nilai keislaman dilakukan pada kelas IIIA MI Zainul Hasan Balung untuk mengetahui kemenarikan atau kelayakan buku ajar. Dari perhitungan yang diperoleh dengan menggunakan rumus persentase kelayakan atau kemenarikan penggunaan buku ajar matematika terintegrasi nilai-nilai keislaman sebesar $84,30 \%$. Sesuai dengan tabel kelayakan atau kevalidan menunjukkan bahwa hasil validasi atau kelayakan pengembangan produk buku ajar matematika terintegrasi nilai-nilai keislaman termasuk dalam kategori sangat menarik.

\section{REFERENSI}

Anggela, M., Masril, \& Darvina, Y. (2013). Pengembangan Buku Ajar Bermuatan NilaiNilai Karakter Pada Materi Usaha Dan Momentum Untuk Pembelajaran Fisika Siswa Kelas XI SMA. Pillar of Physics Education, 1(1), 63-70.

Baharuddin. (2014). Pendidikan \& Psikologi Perkembangan. Jogjakarta: Ar-Ruzz Media Grup.

Cai, J., Kaiser, G., Perry, B., \& Wong, N.-Y. (2009). Effective Mathematics Teaching from Teachers' Perspective (National and Cross-National Studies). Rotterdam: Sense Publishers.

Fathani, A. H. (2012). Matematika: Hakikat $\mathcal{E}$ Logika. Jogjakarta: Ar-Ruzz Media Grup.

Fokusmedia, T. (2015). Undang-Undang SISDIKNAS Sistem Pendidikan Nasional. Bandung: Fokus Media.

Hamzah, A., \& Muhlisrarini. (2014). Perencanaan dan Strategi Pembelajaran Matematika. Jakarta: Rajawali Press.

Samani, M. (2011). Menggagas Pendidikan Bermakna: Integrasi Life Skill-KBK-CTL-MBS. Surabaya: SIC.

Sugiyarti, L., Arif, A., \& Mursalin. (2018). Pembelajaran Abad 21 di Sd. Prosiding Seminar Dan Diskusi Nasional Pendidikan Dasar 2018,439-444.

Sugiyono. (2015). Metode Penelitian Pendidikan (Pendekatan Kuantitatif, Kualitatif dan RED). Bandung: Penerbit CV. Alfabeta.

Sugiyono. (2016). Metode Penelitian Kuantitatif, Kualitatif, dan RED. Bandung: Alfabeta.

Trianto. (2013). Model Pembelajaran Terpadu: Konsep, Strategi, dan Implementasinya dalam Kurikulum Tingkat Satuan Pendidikan. Jakarta: Bumi Aksara. 